\title{
Maturation of the Developing Rabbit Kidney: Variations in Cellular Size and Contents
}

\author{
BARBARA R. COLE, ${ }^{(20)}$ J. TREVOR BROCKLEBANK, BRENDA N. MURRAY, LINDA J. PETERSON, \\ and ALAN M. ROBSON \\ The Edward Mallinckrodt Department of Pediatrics, Washington University School of Medicine, and the Renal \\ Division. St. Louis Children's Hospital, St. Louis, Missouri, USA
}

\begin{abstract}
Summary
Because the rabbit kidney is being used as an experimental model with increasing frequency, this study was designed to measure the relationships between cell number, size, and contents in the developing rabbit. Kidney slice extracellular and intracellular fluid spaces, high in the fetus and neonate, declined as the rabbits matured, being paralleled by changes in body fluid spaces. Although the cellular contents of both sodium and potassium were increased in the young kidney, intracellular sodium concentration was slightly lower in the fetal $(43.6 \mathrm{mEq} /$ liter $)$ and 2-wk kidneys (44.5 $\mathrm{mEq} /$ liter) than in the mature kidney $(51.7 \mathrm{mEq} /$ liter). Intracellular potassium concentrations were similar in all age groups (163 to $167 \mathrm{mEq} /$ liter). Tissue protein content was similar during development. In contrast, DNA content and the number of nuclei in kidney tissue were high in the fetus (DNA, $59.9 \mathrm{mg} / \mathrm{g}$ solids; nuclei, $3.9 \times 10^{9} / \mathrm{g}$ solids), decreasing in postnatal life (DNA in adult, $18.2 \mathrm{mg} / \mathrm{g}$ solids; nuclei in adult, $1.0 \times 10^{9} / \mathrm{g}$ solids). In association with this, the diameter of proximal tubular cells increased with maturation. These data should be valuable to those interested in kidney development.
\end{abstract}

The improved survival of premature human neonates has increased the need for better understanding of the functional capabilities of the neonatal kidney. Many investigations of tubular function in kidneys from adult animals and maturation of these functions in younger animals have been performed in the rabbit $(10,11,13,16-18)$.

The present studies establish values for the increases in cellular number, size, and contents during growth of the rabbit kidney. They also examine the relationships of changes in renal fluid spaces to those in body fluid spaces that occur during development of the fetal rabbit to an adult animal at age 6 months.

\section{MATERIALS AND METHODS}

\section{FLUID SPACES IN ANIMALS}

Measurements of total body water and of extracellular fluid spaces were undertaken using the methods established by Prentice et al. (19) and Berne and Levy (2). Rabbits 1, 2, 4, 8, and 26 wk of age were anesthetized with intravenous pentobarbital. Flank incisions were made, and the renal vessels were ligated to prevent excretion of the radioisotopes. After obtaining a venous blood sample to use as blank, tared amounts of $\left[{ }^{3} \mathrm{H}\right]$ water (New England Nuclear; specific activity, $100 \mathrm{mCi} / \mathrm{g}$ ) and $\left[{ }^{14} \mathrm{C}\right]$ carboxy inulin (New England Nuclear; specific activity, $2.45 \mathrm{mCi} / \mathrm{mg}$ ) were injected intravenously. The animal was kept warm under light anesthesia during a 2-hr equilibration period at which time a repeat venous blood sample was drawn. Aliquots of the initial injection solution and the blood were counted in a Tri-Carb liquid scintillation Counter (Packard model 3375) using standard techniques to separate ${ }^{14} \mathrm{C}$ from ${ }^{3} \mathrm{H}$ counts. The distribution spaces of ${ }^{3} \mathrm{H}$ and ${ }^{14} \mathrm{C}$ were taken as estimates of total body water and extracellular space, respectively, and expressed as percentage of body weight.

\section{FLUID SPACES AND ELECTROLYTE CONTENT OF KIDNEYS}

Kidney cortical tissue was prepared and incubated using methodology described previously (7), studying animals ranging in age from 29 days gestation to $26 \mathrm{wk}$. In brief, 0.3 to $0.4 \mathrm{~mm}$ cortical slices were cut with a Stadie Riggs microtome and then were incubated in a Ringers-phosphate solution oxygenated with $100 \%$ $\mathrm{O}_{2}$ in a shaking water bath at $27^{\circ} \mathrm{C}$. After an hour's incubation, the slices were blotted, weighed, and homogenized in $10 \%$ trichloroacetic acid (TCA) in a manual tissue grinder. The homogenates were filtered, and the filtrate, as well as incubating medium, was analyzed.

In addition to the determinations of inulin previously described (7), measurements of sodium and potassium were performed on a flame photometer. Measurements were made on both tissue filtrates and the incubation medium. The lithium concentration of the diluent was adjusted (12) to allow measurement of the very low levels of these cations in tissue filtrate. Because of these low levels of sodium, it was necessary to take great care to avoid sodium contamination or erroneous sodium measurements in these studies. Acid-washed flasks containing no cortical tissue were run with each experiment, and the values for any sodium measurements from these blank flasks were subtracted from the values observed in the tissue containing samples before further calculations were undertaken. In addition, the sodium concentration in the TCA was measured before it was used for tissue homogenization to ensure that significant quantities of sodium had not been leached either from the containers used to store the TCA or from the glass with which it had come into contact.

The amounts of sodium and potassium in the extracellular fluid space of the tissue were calculated from the tissue inulin space and from the measurements of sodium and potassium in the incubation medium. These values were subtracted from the measured total tissue values to yield an estimate of intracellular sodium and potassium contents. Intracellular sodium and potassium concentrations could be calculated from these values and from the estimates of intracellular water content.

\section{PROTEIN AND DNA CONTENT OF KIDNEY}

Cortical tissue was incubated as described above. The tissue was homogenized and poured into a polycarbonate tube where it then stood on ice for $30 \mathrm{~min}$. The extraction procedure was modified from previously described procedures (3-6) as follows: after centrifuging the sample in TCA, the pellet was washed in ethanol and spun. One $\mathrm{N}$ perchloric acid was added to the pellet and incubated at $80^{\circ} \mathrm{C}$ for $20 \mathrm{~min}$. This mixture was centrifuged, additional $0.5 \mathrm{~N}$ perchloric acid was added to the pellet, and the tube was respun. One hundred $\mu$ l of supernate was added to 2000 $\mu l$ of diphenylamine reagent, incubated at $37^{\circ} \mathrm{C}$ for $18 \mathrm{hr}$, and read on a Coleman Spectrophotometer (model 55) at $500 \mathrm{~nm}$.

Five-tenths $\mathrm{N} \mathrm{NaOH}$ was added to the remaining pellet, incu- 
bated overnight at $37^{\circ} \mathrm{C}$, and analyzed for protein by the method of Lowry et al. (14).

\section{DETERMINATION OF NUMBER OF NUCLEI IN KIDNEY}

The method of isolating nuclei to be counted under a light microscope was an adaptation of several procedures $(1,8,9)$. Kidneys were obtained as described above. Approximately $1 \mathrm{~g}$ of cortical slice was weighed and homogenized in $10 \mathrm{ml} 2 \%$ citric acid using a motor-driven Teflon homogenizer (A. H. Thomas). The hypotonicity of the solution and the homogenizer were effective in lysing cells. The acidity of the solution was instrumental in preserving the integrity of the nuclei (9).

To the homogenate $30 \mathrm{ml} 2 \%$ citric acid were added, and the sample was spun in a refrigerated centrifuge at $1500 \mathrm{rpm}$ for 10 min. The supernate was discarded, and $40 \mathrm{ml} 2 \%$ citric acid were added to the sediment. This suspension was spun at $1000 \mathrm{rpm}$ for $10 \mathrm{~min}$. After discarding the supernate, the sediment was resuspended in another $40 \mathrm{ml} \mathrm{2 \%}$ citric acid and spun at $700 \mathrm{rpm}$ for 10 min. The sediment was resuspended in $40 \mathrm{ml} 2 \%$ citric acid, and after thorough mixing, the nuclei were counted in a Levy double counting chamber (Fisher Scientific Co.). The mean of five counts was taken as one observation. Examination of the suspension with high magnification verified the absence of whole cells or significant debris.

\section{MEASUREMENT OF PROXIMAL TUBULAR CELL DIAMETER}

Cell diameter was measured as follows: individual nonincubated kidneys from each age group were fixed in formalin and sectioned. Sections were stained by routine procedures with hematoxylin and eosin. Photomicrographs of superficial cortical and juxtamedullary regions were taken using a Polaroid camera at a magnification of $\times 400$. Proximal tubular cells were identified by their histologic characteristics with diameters of these cells being measured from the photomicrographs using a millimeter rule. Only cells thought to be sectioned through their equator were included in these measurements.

\section{STATISTICAL METHODS}

Values from each age group were compared with those for the 26-wk animals using the Student $t$ test for nonpaired data. In addition, correlation coefficients were determined by linear regression analysis to determine linearity of change from fetal to mature ages.

\section{RESULTS}

\section{BODY FLUID SPACES (TABLE 1)}

The rabbits grew rapidly after birth, their weights increasing in a near-linear pattern up to 8 wk of age. At 1 wk of age when the rabbits The rabbits grew rapidly after birth, their weights increasing in a near-linear pattern up to $8 \mathrm{wk}$ of age. At 1 wk of age when the rabbits were first large enough to obtain reliable measurements, total body water $\left(\left[{ }^{3} \mathrm{H}\right]\right.$ water space $)$ and extracellular fluid $\left(\left[{ }^{14} \mathrm{C}\right]\right.$ inulin space) were quantitated. Values for both spaces when expressed per unit of body weight were higher than those observed in the adult rabbits. The extrapolated value for intracellular fluid space was also increased in the 1-wk-old animals. Regression analyses for total water and extracellular fluid spaces (ECF) demonstrated significant linear change with age.

\section{KIDNEY SLICE FLUID SPACES (TABLE 2)}

The sizes of the fluid spaces in the kidney slices obtained from rabbits of different ages are compared in Table 2 . As in the intact animals, water comprised more than $80 \%$ of tissue weight in the fetal and very young animals. This was due to higher values for both intracellular fluid spaces and ECF in the younger animals. When expressed as $\mathrm{ml} / \mathrm{kg}$ tissue solids, both ECF and intracellular

Table 1. Alterations in body weight and fluid spaces in the developing rabbit

\begin{tabular}{|c|c|c|c|c|c|}
\hline $\begin{array}{l}\text { Age } \\
\text { (wk) }\end{array}$ & No. of animals & $\begin{array}{l}\text { Rabbit wt } \\
(\mathrm{kg})\end{array}$ & $\begin{array}{l}\text { Total water } \\
\text { (\% body wt) }\end{array}$ & $\begin{array}{c}\mathrm{ECF}^{2} \\
(\% \text { body wt) }\end{array}$ & $\begin{array}{c}\text { Intracellular fluid spaces } \\
\text { Total water-ECF } \\
\text { (\% body wt) }\end{array}$ \\
\hline 1 & 3 & $0.12 \pm 0.01^{3,4}$ & $82.9 \pm 1.2^{4}$ & $21.8 \pm 0.8^{5}$ & $61.1 \pm 0.2^{4}$ \\
\hline 4 & 3 & $0.98 \pm 0.06^{4}$ & $77.0 \pm 1.4$ & $20.2 \pm 1.3$ & $56.8 \pm 2.5^{5}$ \\
\hline 8 & 3 & $1.76 \pm 0.14^{4}$ & $65.7 \pm 2.0$ & $17.0 \pm 0.4$ & $48.7 \pm 2.4$ \\
\hline 26 (adult) & 7 & $3.79 \pm 0.13$ & $65.7 \pm 3.2$ & $16.1 \pm 1.2$ & $49.3 \pm 2.3$ \\
\hline
\end{tabular}

${ }^{1}$ Measured as $\left[{ }^{3} \mathrm{H}\right]$ water space.

${ }^{2}$ Measured as $\left[{ }^{14} \mathrm{C}\right]$ inulin space.

${ }^{3}$ Mean \pm S.E.

${ }^{4}$ Significantly different than $P<0.01$

"Significantly different with $P<0.05$.

${ }^{6} r$ values are those calculated by linear regression; asterisks indicate $P$ values calculated from $t$ values.

Table 2. Comparison of sizes of fluid compartments in the developing rabbit kidney

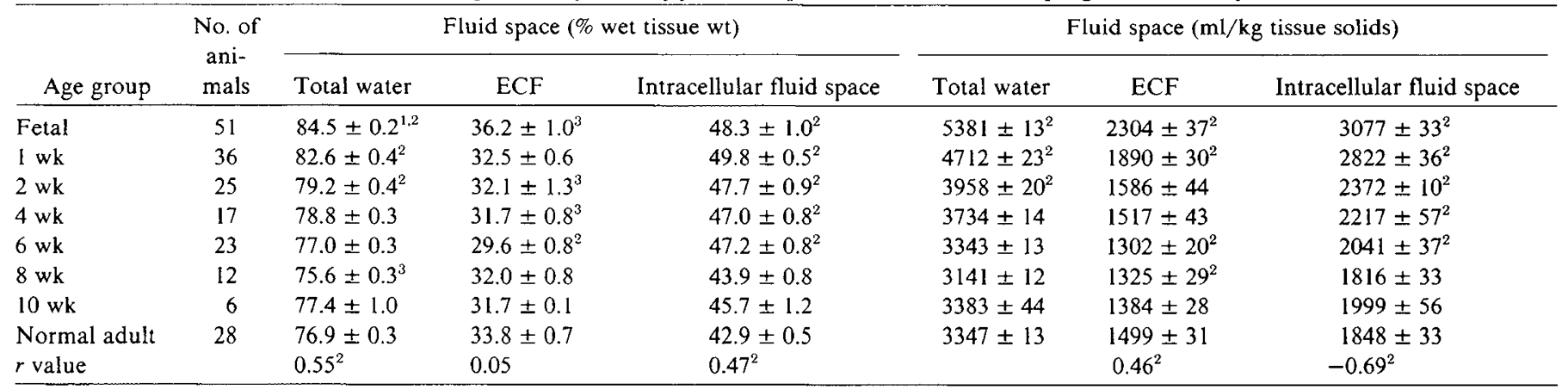

\footnotetext{
${ }^{1}$ Mean \pm S.E.

${ }^{2}$ Significantly different than $P<0.01$

${ }^{3}$ Significantly different with $P<0.05$.
} 
Table 3. Tissue and intracellular sodium and potassium levels in kidney cortex slices obtained from animals of different ages

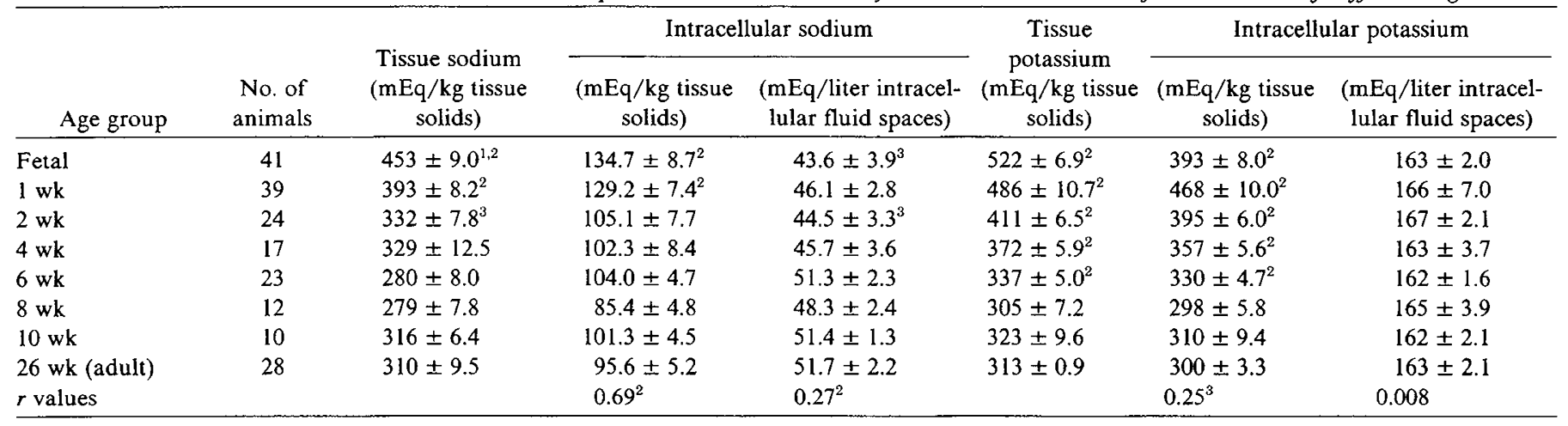

${ }^{1}$ Mean \pm S.E.

${ }^{2}$ Significantly different than $P<0.01$.

${ }^{3}$ Significantly different with $P<0.05$.

Table 4. Comparison of cellular constituents in developing kidney

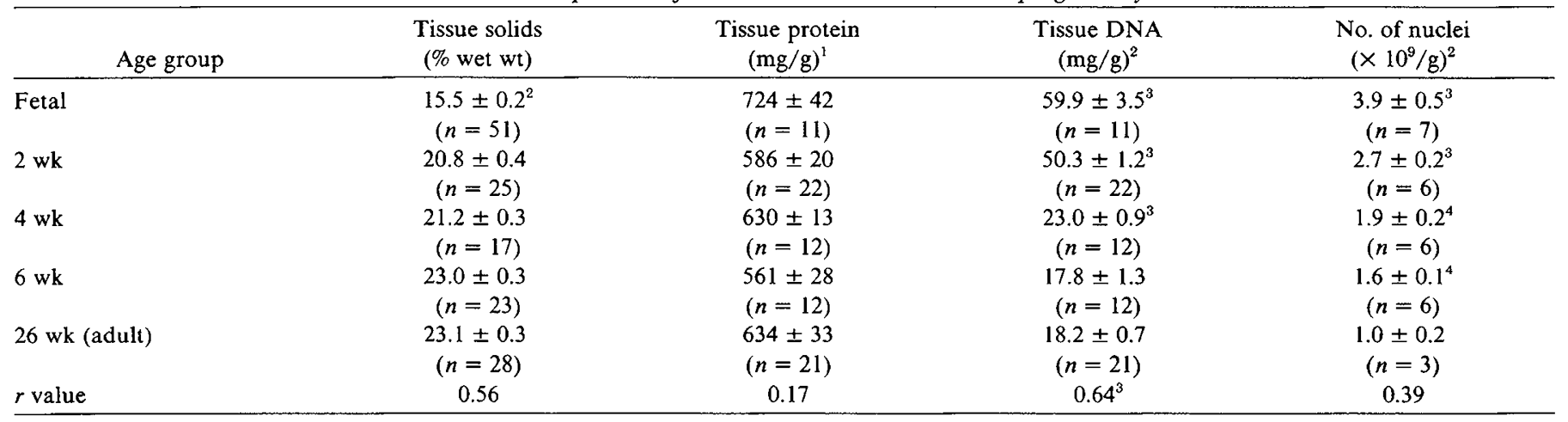

${ }^{1}$ Expressed per gram of tissue solids.

${ }^{2}$ Mean \pm S.E.

${ }^{3}$ Significantly different than $P<0.01$.

${ }^{4}$ Significantly different with $P<0.05$.

fluid spaces values gradually declined to adult levels as the animals matured.

\section{SODIUM AND POTASSIUM CONTENTS OF KIDNEY TISSUE (TABLE 3)}

Total tissue sodium, expressed per unit of tissue solids, was significantly higher in the fetal and 1- and 2-wk-old animals than in the more mature rabbits. Because the fluid spaces were greater in these younger animals, however (Table 2), total tissue sodium remained similar in all age groups when the values were expressed in terms of wet tissue weight. Intracellular sodium content expressed per $\mathrm{kg}$ of tissue solids was also increased in the fetal and 1-wk-old rabbits, and when intracellular sodium concentrations were calculated (Table 3), only the fetal and 2-wk-old kidneys showed statistically significant differences. Linear regression did, however, show a significant, albeit small, increase with age.

Maturation of total tissue and intracellular potassium content and concentrations revealed a similar pattern to that seen with sodium. Total tissue and intracellular potassium contents, expressed per unit of tissue solids, were increased in the younger animals. However, intracellular potassium concentration, expressed as $\mathrm{mEq} /$ liter of intracellular fluid, was remarkably similar in animals of all ages.

To determine whether the depth of slice had influence on water content or intracellular sodium and potassium concentrations, four slices were cut from the kidneys of 2-wk-old animals. Slices from the respective levels were incubated together, and values were compared. No statistically significant differences were seen in values among the various levels.

\section{PROTEIN DNA AND NUCLEAR CONTENTS OF KIDNEYS (TABLE 4)}

As expected from the data on fluid spaces (Table 2), tissue solids represented a smaller percentage of total tissue weight in
Table 5. Measurement of the diameter of proximal tubular cells during development of the rabbit kidney

\begin{tabular}{lcl}
\hline & \multicolumn{2}{c}{$\begin{array}{c}\text { Cellular diameter }(\mu) \\
\text { (Region) }\end{array}$} \\
\cline { 2 - 3 } \multicolumn{1}{c}{ Age group } & Superficial cortical & Juxtamedullary \\
\hline Fetal & $10.1 \pm 0.15^{1,2}$ & $12.5 \pm 0.18^{2}$ \\
$2 \mathrm{wk}$ & $11.3 \pm 0.26^{2}$ & $15.0 \pm 0.20^{2}$ \\
$4 \mathrm{wk}$ & $16.0 \pm 0.30$ & $14.5 \pm 0.25^{2}$ \\
$6 \mathrm{wk}$ & $15.8 \pm 0.30^{3}$ & $18.0 \pm 0.28$ \\
$8 \mathrm{wk}$ & $15.3 \pm 0.15^{3}$ & $16.0 \pm 0.18^{2}$ \\
Adult & $20.3 \pm 0.20$ & $18.8 \pm 0.50$ \\
$r$ values & $0.70^{2}$ & $0.63^{2}$ \\
\hline
\end{tabular}

${ }^{1}$ Mean \pm S.E

${ }^{2}$ Significantly different than $P<0.01$.

${ }^{3}$ Significantly different with $P<0.05$.

the kidneys from the neonatal animals than in kidneys from more mature animals. The value progressively increased with increasing age, the adult value of $23.1 \%$ being reached in 6-wk-old animals. Tissue protein represented a constant percentage of tissue solids. Although this value was higher in the neonatal kidney than in those at any other age, the differences did not reach statistical significance.

In contrast, tissue DNA represented a significantly higher percentage of tissue solids in the fetal kidneys. The relative amount of DNA declined progressively with increasing maturation to reach the adult value in the 6 -wk-old animals. In keeping with the data on DNA, the number of nuclei per $g$ of tissue solids was also higher in the kidneys from the fetal animals than in those from older animals. 
Table 6. Maintenance of cellular integrity in the absence of exogenous substrate

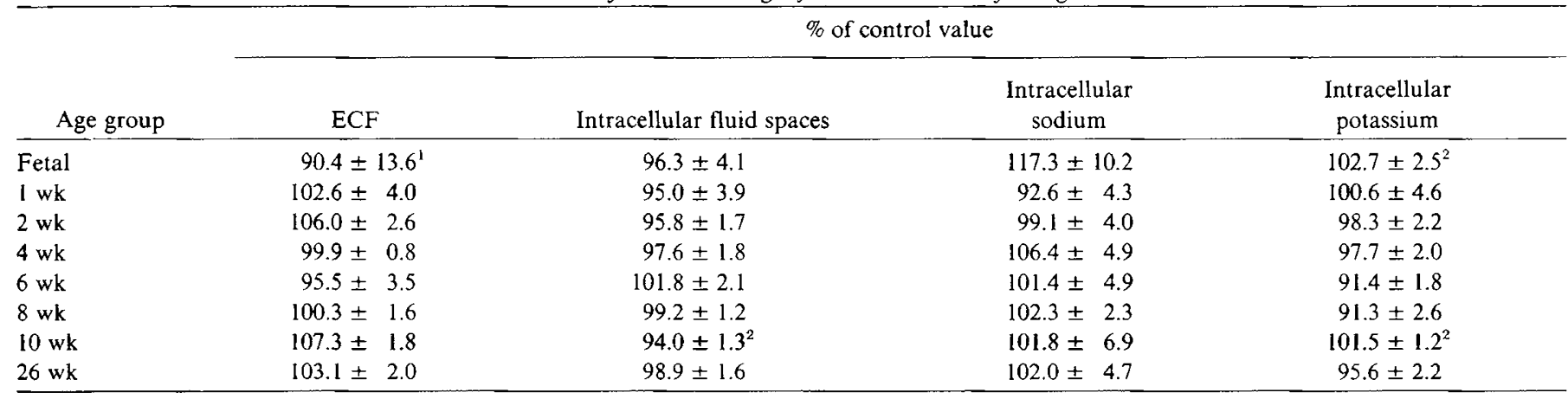

${ }^{1}$ Mean \pm S.E.

${ }^{2} P<0.05$ compared to the adult values using the Student $t$ test for nonpaired data.

Table 7. Comparison of values from kidney tissue obtained from pregnant and nonpregnant adult rabbits

\begin{tabular}{|c|c|c|c|}
\hline Measurement & Adult & $\begin{array}{l}\text { Pregnant } \\
\text { adult }\end{array}$ & $P^{1}$ \\
\hline $\begin{array}{l}\text { Tissue ECF (ml/kg tissue } \\
\text { solids) }\end{array}$ & $\begin{array}{c}1499 \pm 31^{2} \\
(n=28)\end{array}$ & $\begin{array}{c}1743 \pm 39 \\
(n=16)\end{array}$ & $<0.01$ \\
\hline $\begin{array}{l}\text { Tissue intracellular fluid } \\
\text { spaces (ml/kg tissue } \\
\text { solids) }\end{array}$ & $\begin{array}{c}1848 \pm 33 \\
(n=28)\end{array}$ & $\begin{array}{c}1794 \pm 78 \\
(n=16)\end{array}$ & $\mathrm{NS}^{3}$ \\
\hline $\begin{array}{l}\text { Tissue sodium }(\mathrm{mEq} / \mathrm{kg} \\
\text { tissue solids) }\end{array}$ & $\begin{array}{l}310 \pm 9.5 \\
(n=28)\end{array}$ & $\begin{array}{l}339 \pm 18.4 \\
(n=16)\end{array}$ & $<0.05$ \\
\hline $\begin{array}{l}\text { Intracellular sodium } \\
(\mathrm{mEq} / \text { liter })\end{array}$ & $\begin{array}{l}51.7 \pm 2.2 \\
(n=28)\end{array}$ & $\begin{array}{l}52.6 \pm 2.2 \\
(n=16)\end{array}$ & NS \\
\hline $\begin{array}{l}\text { Tissue } \mathrm{K} \text { (mEq/kg tissue } \\
\text { solids) }\end{array}$ & $\begin{array}{l}313 \pm 0.9 \\
(n=28)\end{array}$ & $\begin{array}{l}295 \pm 9.3 \\
(n=16)\end{array}$ & NS \\
\hline Intracellular $\mathrm{K}$ (mEq/liter) & $\begin{array}{l}163 \pm 2.1 \\
(n=28)\end{array}$ & $\begin{array}{l}155 \pm 3.6 \\
(n=16)\end{array}$ & NS \\
\hline $\begin{array}{l}\text { Tissue protein }(\mathrm{g} / \mathrm{kg} \text { tissue } \\
\text { solids) }\end{array}$ & $\begin{array}{l}634 \pm 33 \\
(n=21)\end{array}$ & $\begin{array}{l}743 \pm 28 \\
(n=12)\end{array}$ & $<0.05$ \\
\hline $\begin{array}{l}\text { Tissue DNA (g/kg tissue } \\
\text { solids) }\end{array}$ & $\begin{array}{l}18.2 \pm 0.7 \\
(n=21)\end{array}$ & $\begin{array}{c}20.6 \pm 0.8 \\
(n=12)\end{array}$ & $<0.05$ \\
\hline $\begin{array}{l}\text { Nuclear count }\left(\times 10^{9} / \mathrm{g} \text { tis- }\right. \\
\text { sue solids })\end{array}$ & $\begin{array}{c}1.0 \pm 0.2 \\
(n=3)\end{array}$ & $\begin{array}{l}0.87 \pm 0.2 \\
\quad(n=5)\end{array}$ & NS \\
\hline
\end{tabular}

${ }^{1}$ Using Student $t$ test for paired data.

${ }^{2}$ Mean \pm S.E.

${ }^{3} \mathrm{NS}$, not significant.

\section{PROXIMAL TUBULAR CELL SIZES (TABLE 5)}

There was a progressive increase in the size of proximal tubule cells in both the superficial cortical and juxtamedullary regions of the cortex. The mean diameter of the superficial cortical cell increased from $10.1 \mu$ in the fetus to $20.3 \mu$ in the adult rabbit while the mean diameter of the juxtamedullary cell rose from 12.5 to $18.8 \mu$ during development.

\section{MAINTENANCE OF CELLULAR INTEGRITY IN THE ABSENCE OF EXOGENOUS SUBSTRATE (TABLE 6)}

Slices from rabbit kidneys of each age group were incubated in paired flasks of incubation medium, one containing $10 \mathrm{mM}$ sodium acetate and the other no exogenous substrate, the sodium acetate being replaced by equimolar amounts of sodium chloride. Despite the absence of exogenous substrate, the kidneys slices from animals of all ages were able to maintain the intracellular sodium and potassium concentrations found in tissue incubated in the presence of exogenous substrate.

\section{INFLUENCE OF PREGNANCY (TABLE 7)}

In th studies of fetal kidney tissue, the kidneys from the pregnant animals were also studied. Table 7 compares these results to those from nonpregnant adult animals. Kidney cortex from the pregnant animals had significantly higher contents of tissue water, sodium, protein, and DNA. However, intracellular sodium concentrations were maintained at levels comparable to those of the nonpregnant animal adults.

\section{COMMENT}

Nash and Edelmann (15) have suggested that use of the term "immature" may be inappropriate for describing renal function during development. Although immature describes a difference between function in the developing organism and the adult, such differences may well be appropriate for the state of the development of that organism. The composition of the fetal tissue differs from that of more mature animals. These changes do not reflect those induced by pregnancy in the mother. The fetus, living in a fluid environment, has a high content of water. Postnatally, the rabbit, as well as other mammals living in a terrestial environment, lose water from both extracellular and intracellular spaces so that tissue solids represent an increased proportion of wet tissue weight with normal growth and development. The present study demonstrates the importance of expressing data from young animals in the appropriate manner. Failure to do so could result in observations that are liable to be misinterpreted as representing "immaturity" in the younger animal. Thus, comparing tissue contents at different ages using total tissue water as the denominator may underestimate the values at young ages because water comprises a higher percentage of tissue weight at these ages. Conversely, factoring by tissue solids may overestimate values of the young. Only by factoring cellular contents by cellular water at each age can one demonstrate the constancy of the cellular composition and appreciate the maturity of the internal milieu during growth.

\section{REFERENCES AND NOTES}

1. Arnesan, K., Goldsmith, Y., and Dulaney, A. D.: Antigenic properties of nuclei segregated from spleens of normal and leukemic mice. Cancer Res., 9: 669 (1949)

2. Berne, R. M., and Levy, M. N.: A modified procedure for determining inulin space. Proc. Soc. Exp. Biol. Med., 77: 582 (1951).

3. Burton, K.: A study of the conditions and mechanism of the diphenylamine reaction for the colorimetric estimation of deoxyribonucleic acid. Biochem. J., 62: 315 (1956)

4. Burton. K.: Determination of DNA concentration with diphenylamine. Methods Enzymol., 12: 163 (1968).

5. Ceriotti, G.: A microchemical determination of desoxyribonucleic acid. J. Biol Chem., 198: 297 (1952).

6. Ceriotti, G.: Determination of nucleic acids in animal tissues. J. Biol. Chem., 214: 59 (1955)

7. Cole, B. R., Brocklebank, J. T., Capps, R. G., Murray, B. N., and Robson, A. M. Maturation of PAH transport in the developing rabbit kidney. Interrelationships of the individual components. Pediatr. Res., 12: 992 (1978).

8. Dounce, A. L.: Enzyme studies on isolated cell nuclei of rat liver. J. Biol. Chem., 147: 685 (1943).

9. Dounce, A. L. Witter, R. F., Monty, K. J., Pate, S., and Cottone, M. A.: A method for isolating intact mitochondria and nuclei from the same homogenate, and the influence of mitochondrial destruction on the properties of cell nuclei. J. Biophys. Biochem. Cytol., 1: 139 (1955).

10. Hewitt, W. R., Wagner, P. A., Bostwick, E. F., and Hook, J. B.: Transport ontogeny and selective substrate stimulation as models for identification of multiple renal organic anion transport systems. J. Pharmacol. Exp. Ther., 202: 711 (1977).

11. Horster, M., and Larsson, L.: Mechanisms of fluid absorption during proximal tubule development. Kidney Int., 10: 348 (1976). 
12. Klahr, S., Robson, A. M., Guggenheim, S. J., Tateishi, S., Bourgoignie, J. J., and Hwang, K. H.: Ammonium induced atterations in PAH uptake and cation composition of kidney slices. Am. J. Physiol., 219: 994 (1970).

13. Larsson, L., and Horster, M.: Ultrastructure and net fluid transport in isolated perfused developing proximal tubules. J. Ultrastruct. Res., 54: 276 (1976)

14. Lowry, O. H., Rosebrough, N. J., Farr, A. L., and Randall, R. J.: Protein measurement with the Folin phenol reagent. J. Biol. Chem., 193: 265 (1951).

15. Nash, M. A., and Edelmann, C. M., Jr.: The developing kidney. Immature function or inappropriate standard? Nephron, 11: 71 (1973)

16. Pegg, D. G., Bernstein, J., and Hook, J. B.: Biochemical and ultrastructural correlates of substrate stimulation of renal organic anion transport. Proc. Soc. Exp. Biol. Med., 151: 720 (1976).

17. Pegg, D. G., Hewitt, W. R., and Hook, J. B.: Substrate stimulation of $p$ aminohippuric acid transport: Effect on uptake and runout. Proc. Soc. Exp. Biol. Med., 149: 546 (1975)
18. Pegg, D. G., and Hook, J. B.: Pharmacodynamic analysis of substrate stimulation of $p$-aminohippurate transport by newborn rabbit kidney. J. Pharmacol. Exp. Ther., 195: 16 (1975).

19. Prentice, T. C., Siri, W., Berlin, N. I., Hyde, G. M., Parsons, R. J., Joiner, E. E., and Lawrence, J. H.: Studies on total body water with tritium. J. Clin. Invest., 31: 412 (1952).

20. Requests for reprints should be addressed to: B. R. Cole, M.D., Department of Pediatrics, St. Louis Children's Hospital, 500 South Kingshighway, Post Office Box 14871, St. Louis. MO 63178 (USA).

21. This research was supported in part by special fellowship 5F03HD49, 884 (B. R. C.), by a fellowship from the Kidney Foundation of Eastern Missouri and Metro-East (J. T. B.), by Career Development Award 5K04AM70236 (A. M. R.) and by Program Project Grant AM 09976.

22. Received for publication May 8, 1980.

23. Accepted for publication October 7, 1980.

Copyright $(1981$ International Pediatric Research Foundation, Inc.

Printed in U.S.A. 